\title{
The assassination of King Alexander I of Yugoslavia in the light of archival press articles
}

Outline of content: The article discusses the reasons, circumstances, course of action and early consequences of the assassination of King Alexander I of Yugoslavia in October 1934 in Marseilles, France. Particular focus was paid to the internal situation in the country after the monarch's death, as well as to the factors defining the shaping of relations between the realm of the Karađorđevićs and the international scene. Thus far, the assassination used to be discussed in a rather general way, but the details of the crime committed by Vlado Chernozemski revealed numerous shortcomings and the existence of a broad conspiracy related to the king's visit to France.

Keywords: House of Karađorđević, Kingdom of Yugoslavia during interwar period, King Alexander I, assassination of King Alexander I in 1934

\section{Introduction}

The events of early autumn 1934 did not foreshadow any changes in the Kingdom of Yugoslavia. As a result of a coup carried out six years earlier in January 1929, ${ }^{1}$ the effective power in the country was in the hands of King Alexander I of the House of Karađorđević. His model of government could be described as authoritarian, although King Alexander I did try to maintain a semblance of democracy. The monarch had indeed implemented an administrative reform in October 1929, then decreed a new constitution in September 1931; in the very same year,

\footnotetext{
${ }^{1}$ On 6 January 1929, the so-far reticent King Alexander I performed a bloodless coup in the country. With the support of trusted political and military elites, the monarch outlawed all political parties, then suspended the Yugoslavian parliament and constitution. This decision meant that the Kingdom of SHS was undergoing a de facto regime change: the parliamentary monarchy was being replaced by the king's dictatorship.
} 
he called a parliamentary election, having first restored the previously suspended parliament. For the upcoming years, King Alexander I had envisaged a gradual thawing of his dictatorship and the restoration of full democracy in the country, but, by October 1934, these promises have not been fulfilled.

It should be noted, however, that the harshness of his rule coincided with the improvement of the country's situation in the international scene. Despite a dispute with Italy ruled by Benito Mussolini, Yugoslavia strengthened its position by means of alliances in Central Europe and the Balkans - with Czechoslovakia, Romania, Greece and Turkey (as part of the so-called Little Entente and Balkan Entente). Friendly relations were also cultivated with France. As a result, King Alexander I would be far more concerned by the fissiparous tendencies in the country, especially among the Croats who resorted to political or terrorist methods in their demands of autonomy or complete independence from the Yugoslav kingdom.

Alexander I wished to settle the issue of Croatian separatism by seeking compromise with the political leader of the Croats, Vladko Maček, heir to the tradition of the Croatian Peasant Party, who remained incarcerated since April 1933 on charges of anti-state activities. The king, however, would not reveal the details of his planned reconciliation with Maček, and his hopes for a peaceful settlement of the internal dispute in Yugoslavia were cut short by his assassination on 9 October 1934 during his stay in France. Following his death, the concept of the Yugoslavian state implemented by the House of Karađorđević has de facto collapsed, and the country plunged into chaos. For this reason, the circumstances of the murder of King Alexander I constitute an interesting subject, although not often discussed - especially in Polish and non-Balkan scholarly literature.

Therefore, the aim of the present article is to examine the course of the assault that brought the demise of King Alexander I, as well as to define the circumstances and early consequences of this event, among which particular attention should be paid to the characteristic of the assassin, the premises of the international investigation, and finally, the internal situation in Yugoslavia following the monarch's death.

The essential sources used in the present article are Serbian ${ }^{2}$ and Polish ${ }^{3}$ press reports published shortly after the assassination, as well as the relatively rare studies regarding the event - the recollections of Polish consular officer Jan Meysztowicz in particular.

The results of the research were verified and subjected to analysis based on the findings of contemporary, usually local specialists in this matter, all of whom

\footnotetext{
2 It should be noted that in 1934, the most reliable press source in the Kingdom of Yugoslavia was the newspaper Политика (Politika). The newspaper had not fallen entirely under the influence of King Alexander I's court, and their articles often featured reports from independent correspondents operating in major countries.

3 The Polish press reports cited in the present article were essentially translations of leading French and European newspapers.
} 
are referenced in the bibliography. In the absence of such sources - a quite common occurrence in this case - the author verified his findings by comparing them with archival documents, and by assessing the credibility of the newspapers cited. The translations provided in the present article are the author's own.

\section{Course of events}

The official objective of Alexander I's three-day visit to France was to strengthen the relations between the Little Entente and France. ${ }^{4}$ Polish consular officer in Marseilles Jan Meysztowicz, ${ }^{5}$ who happened to be a witness to the event, also drew attention to the Italian context of the visit, arguing that it was the French side that sought to ease the tense relations between Yugoslavia and Italy. In fact, the government of Gaston Doumergue hoped to gain Mussolini's favour in the view of a future cooperation in the international scene. ${ }^{6}$

Alexander I's visit was commented likewise in the Polish press. Dziennik Poznanski remarked that France had assumed a mediating role between Yugoslavia and Italy. The talks between the two countries appeared promising, given Mussolini's declaration of willingness to find compromise with the Yugoslav monarch. Either way, it was not Il Duce who sought to repair the Italian-Yugoslav relations; at least not as much as the French did. The following statement by influential senator Henry Bérenger clearly reflected the moods of the French political class in this subject: "Time has come to seize the opportunity to reach an agreement between Italy, Yugoslavia and France, thus giving a common ground to protect peace. The restoration of this agreement must be based on a shared and mutual respect of the honour and rights of each party. Serbia and Italy have fought alongside on French soil, and France has struggled as well for the freedom of these nations. The outcome is far too valuable for us to allow it to become obscured and sterilised by some rivalry of prestige and influence"?

On the day of the assassination, Ilustrowany Kuryer Codzienny published an article describing the preparations of French authorities for the visit of Alexander I. According to the article, both the cabinet of Gaston Doumergue and French President Albert Lebrun wanted to confer a unique character to the king's visit. ${ }^{8}$

${ }^{4}$ Arhiv Jugoslavije in Belgrade, Serbia (hereinafter: АJ), Свијем, год. 7, кљ. 13, бр. 22, item 7-1322, Краль Александар разговара са управнииом франиуске школе у Београду после помена Пољь Dумеру, 12 May 1932.

5 The position of Polish consul in Marseilles, and therefore Meysztowicz's superior, was held by Witold Obrębski.

${ }^{6}$ J. Meysztowicz, Czas przeszły dokonany. Wspomnienia ze służby w Ministerstwie Spraw Zagranicznych w latach 1932-1939, prefaced by H. Batowski, Kraków, 1984, p. 73.

7 “Jakie motywy kierowały zbrodniarzem?", Dziennik Poznański, 233 (11 November 1934), p. 1.

8 "Francja przygotowuje wielkie uroczystości ku czci króla Jugosławji", Ilustrowany Kuryer Codzienny, 280 (9 October 1934), p. 3. 
The Kraków-based newspaper reported that President Lebrun would await the monarch at a train station in Paris. When defining the purpose of the visit, the article quoted the words of French Foreign Minister, Louis Barthou, who ensured that "the whole of France would welcome King Alexander enthusiastically as a national hero, as the French were aware of the strength and importance of their friendship with Yugoslavia - a friendship forged in the heat of the struggle for the existence of both nations. France and Yugoslavia were animated by one and the same desire to maintain long-lasting peace and sincere, loyal cooperation". ${ }^{9}$

Alexander I arrived in France around $4 \mathrm{pm}$, on board of the destroyer Dubrovnik. The anchor was dropped at a short distance from the shore. Several motorboats then approached the ship. The monarch boarded one of the boats, followed by French officers and the royal entourage, including Yugoslav Foreign Minister, Bogoljub Jevtić. The party then left in the direction of Marseilles' Old Port. ${ }^{10}$ At the very same time, Queen Maria, wife of Alexander I, was travelling to France by train. ${ }^{11}$ She was to await her husband in Dijon, a town on the route from Marseilles to Paris. ${ }^{12}$

As the Yugoslav king disembarked the motorboat, Meysztowicz drew attention to his magnificent admiral's uniform, decorated with a Grand Cordon of the Legion of Honour. ${ }^{13}$ Alexander I was greeted at the Quai des Belges by a ceremonial delegation, headed by Foreign Minister Louis Barthou as representative of the French Government, and General Alphonse Joseph Georges, representing here the French Army. As he watched the ceremony, Meysztowicz expressed a certain disgust with the disadvantageously looking military band and honour guard of the French infantry, which both played an important role in the welcoming delegation. The Polish official pointed out their inadequately maintained uniforms and antiquated weapons. When describing his impressions, Meysztowicz stated somewhat ironically: "Maybe they went [...] with recreating the ambience of the great war of which Alexander was, after all, a hero on the Serbian front". ${ }^{14}$ It turned out, however, that this was the best equipment available in Marseilles at the time. ${ }^{15}$

After the official welcoming, the Yugoslav ruler and the French delegation mounted the ceremonial Delage car, which began cruising at a slow pace through the streets of Marseilles. Minister Louis Barthou seated himself on the left of

\footnotetext{
9 Ibid.

10 Meysztowicz, Czas przeszły dokonany, p. 76.

11 The Queen suffered from seasickness, which forced her to get off the Dubrovnik shortly after the vessel left the Yugoslav waters.

12 Ж. Петровска, “Атентатот во Марсеј”, Македонска нащија, http://www.mn.mk/aktuelno/496 (access: 5 March 2014).

13 Meysztowicz, Czas przeszły dokonany, p. 76.

${ }^{14}$ Ibid., p. 75.

15 Ibid.
} 
the king, while General Alphonse Joseph Georges - in front of him. The vehicle was moving at the speed specified in the ceremony protocol, i.e. exactly $8 \mathrm{~km} / \mathrm{h}$, driven by chauffeur named Berteleni. ${ }^{16}$

Their first destination was the monument erected on Boulevard de la Corniche to commemorate the soldiers fallen on the eastern front during the World War, as the monarch himself wished to lay a wreath there. In accordance with the plan, the car drove up Canebière street, heading towards Saint-Ferreol street. The politicians were accompanied by a horseback guard of the French gendarmerie called Gardes Mobiles, under the command of Colonel Jules Piollet. ${ }^{17}$ The car was preceded by a cavalcade of eighteen police officers from Marseilles, and followed by two gendarmes on horseback from Gardes Mobiles, and then by vehicles carrying officials and the king's entourage. ${ }^{18}$ The vast crowd, spontaneously cheering in honour of the monarch, was guarded by numerous policemen and one specially designated unit of the French army, the so-called Tirailleurs Sénégalais. Approximately one thousand five hundred officers were deployed in total. They were placed every six meters. Meysztowicz pointed out that both the police and soldiers were facing the car, not the crowd. ${ }^{19}$ It should therefore be stated that the safety of the king and French delegates was protected in a highly unprofessional manner, even for the security standards of that period. ${ }^{20}$

The very moment of the attack has been described by Meysztowicz in the following words:

A few dozen metres from the Old Port, right by the stock exchange building, a man made his way through the front rows of the crowd gathered on the sidewalk, leapt onto the footstep of the vehicle and, almost touching his victims with the barrel, he emptied a whole magazine of his heavy 10-shot Mauser. [...] The whole scene lasted a couple of seconds. The killer's proficiency in the handling of an automatic pistol was proof of some intense training in this matter. The fatally wounded monarch collapsed on the car seat, while General Georges, hit by three bullets, one of which was lodged in his chest, lost consciousness. Minister Barthou, only slightly wounded in the wrist, managed to leave the car on his own. ${ }^{21}$ The police and Gardes Mobiles started shooting rather indiscriminately, killing one

16 First name unknown. See: Петровска, Атентатот во Марсеј.

17 "L'Assassinat du roi Alexandre et de M. Barthou", Le Petit Parisien, 21043 (10 October 1934), p. 3.

18 The first car behind that of King Alexander I, Minister Barthou and General Georges held Minister Jevtić, making him a direct eyewitness to the attack. He was also the first person to assist the dying king. See: Петровска, Атентатот во Mapcej.

19 Meysztowicz, Czas przeszly dokonany, p. 77.

20 The author describes the circumstances of the attack based on Meysztowicz's journal and a 3-minute-long film called Alexander Murdered, shot by Georges Mejat at the time of the murder. The footage later gained international acclaim following its broadcast by Graham McNamee as part of the Universal Newsreel series.

${ }^{21}$ Minister Barthou can clearly be seen in the aforementioned footage as he wanders disoriented, having left the car. 
and injuring several people from the crowd on the sidewalk. The assassin's bullet-riddled corpse trampled by the crowd was lying on the street. All the officials lost their nerve to the point that several minutes passed before someone took care of the wounded Minister Barthou. [...] Medical treatment and transfusion were applied too late. The 72-year-old Barthou died of blood loss. General Georges, on the other hand, managed to survive. ${ }^{22}$

Meysztowicz's account contains some inaccuracies and omissions due to the chaos that occurred. As a matter of fact, the assassin used a semi-automatic Mauser C96 pistol, which he had hidden in a bouquet of flowers. ${ }^{23}$ The murderer approached the monarch with the pretended goal of handing him the flowers, while shouting in French: "Long live the king!". He then fired ten shots from close range, most of which hit the monarch and the general. ${ }^{24}$ According to Ilustrowany Kuryer Codzienny, thirty shots were fired during the whole incident, meaning around twenty were from police officers. ${ }^{25}$

The course of the assassination was also described by Colonel Jules Piollet:

The vehicle carrying King Alexander, Minister Barthou and General Georges was right by the building of the stock exchange, when suddenly I noticed a man jump out of the crowd, who then, having shot at the police officer who stood in his way, ran past my horse, jumped on the steps of the car and began to shoot [...] I spurred my horse, but even though I found myself beside the killer almost immediately, he managed to fire the fatal shots before I cut him in the head with my sword [...] The murderer, despite lying wounded on the ground, did not stop shooting. The bullets hit two more police officers and several other people in the crowd $[\ldots] .{ }^{26}$

The assault took place around $4.20 \mathrm{pm}$, about ten minutes before the planned laying of the wreath at the monument on Boulevard de la Corniche. The monarch suffered gunshot wounds to the left hand, left arm and right shoulder. The fatal bullet pierced the kings' body on the right side of the chest and reached the liver. Alexander I, bleeding from the mouth and dying in the rear seat of the car, kept his eyes open until his very last breath. ${ }^{27}$ Due to the chaos that ensued,

${ }^{22}$ Meysztowicz, Czas przeszły dokonany, pp. 77-78.

${ }^{23}$ The exact dimensions of the weapon: length $-28.8 \mathrm{~cm}(63.3 \mathrm{~cm}$ with the stock), weight $-1.24 \mathrm{~kg}$. At that time, this Mauser model cost 500 French francs. The assassin's weapon is now on display at the National Museum in Belgrade. "Wyrok śmierci na króla Aleksandra", Ilustrowana Republika, 281 (12 October 1934), p. 2; “Марсељска трагедија у свима својим узбудљивим и тешким појединостима”, Политика, 9486 (14 October 1934), p. 6.

24 Ibid.

25 “Tajemnica spisku na króla Aleksandra i min. Barthou”, Ilustrowany Kuryer Codzienny, 283 (12 October 1934), p. 1.

26 “Ostatnie chwile króla Aleksandra i min. Barthou”, Dziennik Poznański, 233 (11 October 1934), p. 2.

27 “Престоница је с љубављу и оданошћу дочекала свога младог Краља", Политика, 9486 (14 October 1934), p. 5. 


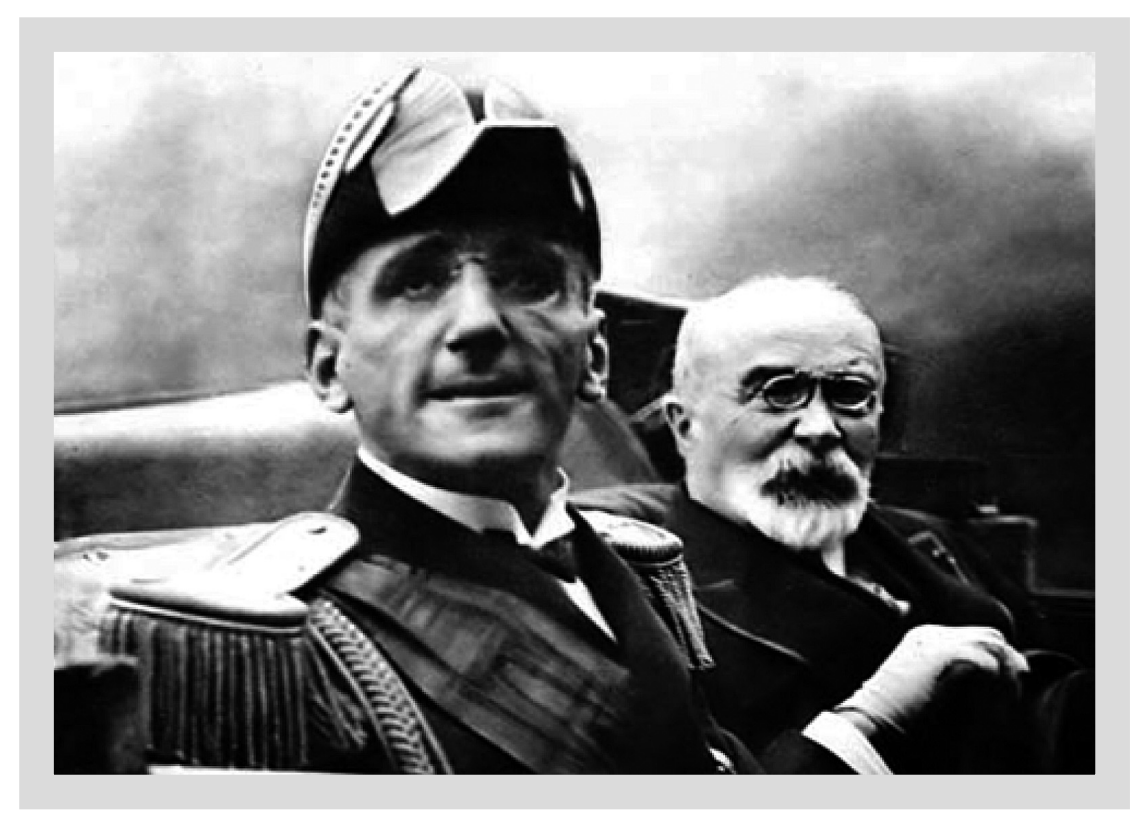

1. King Alexander I and Louis Barthou several moments before the attack in Marseilles, 9 October 1934, in: Arhiv Jugoslavije in Belgrade, bs., Краль Александар и Луј Барту неколико тренутака пре атентата у Марсељу, 9 октобар 1934.

he was brought to the nearest police station rather than the hospital. The rescue operation was led by Dr. Cammenar. ${ }^{28}$ The monarch had lost all vital functions around $5.05 \mathrm{pm}$, three quarters of an hour after the attack. ${ }^{29}$ However, his body was already in a moribund state shortly after receiving the fatal shot. According to the minister Bogoljub Jevtić, the last words whispered by the king were: "Protect me Yugoslavia", but that could have also been "Protect Yugoslavia". ${ }^{30}$

Also interesting was the description of the first moments after the monarch's passing, when his body was lying at the police station. The following account was published by Ilustrowana Republika, based on French sources:

As soon as the doctors pronounced the king dead, his corpse was laid on a couch and covered with a tri-colour banner. The king's hands are folded on his chest. His face is calm, but completely devoid of blood. All electric lights have been turned off, leaving only two lighted candles. A guard of honour is standing on both sides. The carpet before the corpse is covered with flowers. The sobs of the old royal butler can be heard from next door. This man dedicated his life to the education of the young prince Alexander and

28 First name unknown.

${ }^{29}$ L'Assassinat du roi Alexandre, p. 3.

30 The translation from Serbian does not settle the doubt in this matter, while other sources quote the two versions alternately. Whatever they were, these words reflected the sincere love of King Alexander I for Yugoslavia. See: Петровска, Атентатот во Марсеј. 
suffered his fate with him during the Great War. In the neighbouring room are Serbian journalists who had been greeting the king enthusiastically just one hour prior. Everyone has tears in their eyes. ${ }^{31}$

The chauffeur, Berteleni, was killed on the spot, while Minister Louis Barthou died around $5.40 \mathrm{pm}$ on the operating table of a public hospital in Marseilles. At first, it was speculated that the French diplomat could have died from a bullet shot by a policeman, but it was soon found beyond any reasonable doubt that the minister had died from a ricochet of a bullet aimed at the monarch. The head of French diplomacy succumbed to an excessive blood loss caused by the negligence of the rescue personnel who ignored his wounds. Barthou had to stop some car himself in order to be taken to said hospital. ${ }^{32}$ The diplomat's operation was dramatic; his left hand was amputated, which led to a massive haemorrhage. Despite the efforts of doctors, Barthou died, even though he had not lost consciousness during the amputation, constantly inquiring about the health of King Alexander I. His condition worsened dramatically with the haemorrhage. Barthou then uttered his last words: "I'm in pain", after which he lost consciousness and passed. ${ }^{33}$

On the other hand, the gravely wounded General Georges survived the attack. According to Ilustrowana Republika, the general's life was spared by the order pinned to his uniform right above his heart. From the many awards that General Georges could boast about, that day he chose to wear the Serbian Order of St. Sava, made with a material so strong that it changed the trajectory of the bullet. ${ }^{34}$ It was General Georges, along with the chauffeur Berteleni, who tried to prevent the murder by getting into a scuffle with the killer. The resulting confusion led to the death of at least six people from the bullets of French police officers; the victims were identified as MM. Armellin, Dupré, Durbec and Faris, as well as Mme Dumazert and her son. ${ }^{35}$ At least one police officer also died in the incident. ${ }^{36}$

The first onlooker to throw himself in pursuit of the assassin was a man named Pelicier. It was him who knocked the bewildered assassin to the ground and started punching him. However, the Marseilles police officers responded by battering Pelicier, assuming that he was an accomplice of the killer, to then escort him in handcuffs for interrogation, during which he was subjected to torture. A few days later it became clear that Pelicier had no connection with the murderer of the king. After his release, the unlucky hero was immediately taken to the hospital

31 "Król Aleksander Jugosłowiański zamordowany", Ilustrowana Republika, 278 (10 October 1934), p. 2.

32 "Minister Barthou mógł być uratowany", Ilustrowana Republika, 281 (12 October 1934), p. 2.

33 Ostatnie chwile króla Aleksandra, p. 2.

34 “Order uratował życie gen. George'a”, Ilustrowana Republika, 281 (12 October 1934), p. 2.

${ }_{35}$ Краљ Александар I погинуо је јуче по подне у Марсељу као жртва злочиначког атентата, Политика, 10 October 1934, no. 9482, p. 3; Престоница је с љубављу, p. 5; L’Assassinat du roi Alexandre, p. 3.

${ }^{36}$ Ibid. 
due to his serious condition. The Marseilles police force, the same one that beat and tortured Pelicier, then expressed gratitude to the brave citizen for his courageous behaviour. What they forgot about, on the other hand, was an apology. ${ }^{37}$

\section{Identity of the killer}

The perpetrator of the attack was Vlado Chernozemski, a Bulgarian contract killer, prison recidivist and a regular member of the Internal Macedonian Revolutionary Organisation (IMRO). At the beginning of the 1930s, Chernozemski also undertook active cooperation with Croatian revolutionary terrorists, the Ustaše, acting as an instructor for assassins at their training camp in Janka Puszta, Hungary. ${ }^{38}$ Contrary to Meysztowicz's report, the assassin did not die at the scene. Having just fired his shots, he was hit by Colonel Piollet with a sabre, shot by one of the police officers and pummelled by the angry crowd while the police stood and watched. The police allowed the mob to bring its own justice, but the badly beaten Chernozemski survived the lynching. The killer also attempted to commit suicide by shooting himself in the mouth, but his gun was knocked out of his hand in the resulting chaos. ${ }^{39}$

Shortly after the attack, the French secret service attempted to interrogate Chernozemski; however, he was unable to utter a single word, as his face had been disfigured to such an extent that the subsequent identification of the corpse was based on the tattoo symbolising his commitment to the IMRO - a skull and bones with the initials of the organisation. ${ }^{40}$ Chernozemski died around $8 \mathrm{pm}$ that day. ${ }^{41}$ According to Žaklina Petrovska, the French police officers resorted to extremely brutal methods of torture during the interrogation at the security office, which accelerated the already semi-conscious killer's demise. ${ }^{42}$ Chernozemski's condition was confirmed by an account of a correspondent from Vienna quoted in Ilustrowany Kuryer Codzienny: "His face is completely crushed, to the extent that it cannot be identified". ${ }^{43}$

The body search revealed that, in addition to the aforementioned weapon, Chernozemski carried another Walther pistol, two bombs, a compass and 1,700 French francs. It was determined that the killer had been staying in France since 29 September 1934; first in Paris, and then near Marseilles, about

\footnotetext{
37 "Marsylczyk, który rzucił się na zabójcę", Ilustrowana Republika, 282 (13 October 1934), p. 1.

38 И. Гаджев, История на българската емиграция в Северна Америка, София, 2003, р. 259; Внатрешна македонска револуицонерна организација - Демократска партија за македонско национално единство, http://vmro-dpmne.org.mk (access: 5 March 2014).

39 Ibid.

40 The tattoo was about $5 \mathrm{~cm}$ wide and read "Liberty or Death", "Morderca jest obywatelem czeskim, narodowości chorwackiej”, Dziennik Poznański, 233 (11 October 1934), p. 2.

${ }^{41}$ Краљ Александар I, p. 3.

42 Петровска, Атентатот во Марсеј.

43 Tajemnica spisku na króla Aleksandra, p. 1.
} 


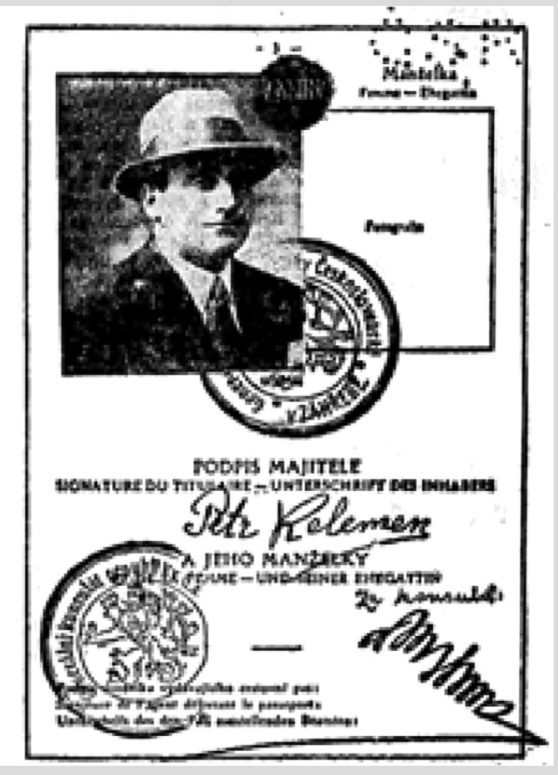

2. One of the pages of the fake passport used by Vlado Chernozemski; after: “Марсељска трагедија у свима својим узбудљивим и тешким појединостима", Политика, 9486 (14 October 1934), p. 6.
$30 \mathrm{~km}$ from the city. On that fateful day, the assassin had drunk a large amount of alcohol. ${ }^{44}$ Chernozemski, who was also known under his real name Velichko Dimitrov Kerin and the pseudonym Vlado the Chauffeur, arrived in Marseilles, using a false passport issued by the Czechoslovak consulate in Zagreb in the false name Peter Kelemen. ${ }^{45}$ The assassination was initially attributed to this moniker, but the reporters of Politika have then found out and announced on 11 October 1934 that no person of that name currently existed. ${ }^{46}$

The head of the Czechoslovak consulate in Zagreb asserted that his office had never issued a passport in the name Kelemen. He did, however, offer his assistance in resolving any formal issues. ${ }^{47}$ It soon became apparent that the passport number corresponds to the document issued to a former Foreign Legion soldier,

Anton Vavrina. The legal owner of the passport had journeyed in Yugoslavia shortly before the events in Marseilles and lost the document there. ${ }^{48}$

Accordingly, the subsequent mentions of the murderer in Politika still referred to him as Kelemen, but now written in quotation marks. Chernozemski's name, along with a photograph of his face and distinctive chest tattoo, first appeared in that newspaper on 17 October 1934. The true identity of the assassin was determined only after his exhumation in the presence of his wife, Mrs Karnisheva, a woman of Bulgarian origin suspected of committing several murders in the Balkans. ${ }^{49}$

\footnotetext{
44 “Morderca miał wspólników”, Dziennik Poznański, 234 (12 October 1934), p. 1.

45 The profession stated in the assassin's passport was "merchant", Tajemnica spisku na króla Aleksandra, p. 1.

46 "У Загребу не постоји ни трговац, ни трговина Петра Келемена, нити ико човека под тим именом познаје”, Политика, 9483 (11 October 1934), p. 10.

47 “Morderca króla i min. Barthou - kto on?”, Ilustrowana Republika, 280 (11 October 1934), p. 2; "Po zamachu w Marsylji", Gazeta Lwowska, 242 (12 October 1934), p. 3.

48 Ibid.

49 “Дефинитивно је утврђен идентитет марселсљког убице”, Политика, 9489 (17 October 1934), p. 7.
} 


\section{First hours after the attack}

The atmosphere in Marseilles on the night from 9 to 10 October 1934 was depressing. The local residents protested shouting: "Marseilles est déshonorée!" ${ }^{50}$ They demanded a quick investigation of the assassination and chanted anti-government slogans. The local newspapers also blared against the French government. Doumergue's cabinet was partly blamed for the death of Yugoslav monarch. The main argument raised in this matter pertained to the current French asylum laws for immigrants. The press called for the abolition of this law or, at least, for a tighter control of foreigners entering France. ${ }^{51}$ The same newspapers also urged the city authorities to erect a statue of the king, as a symbol of French-Yugoslav friendship. ${ }^{52}$ The financial resources for the execution of this idea were collected by eminent French Marshal Louis Franchet d'Esperey. ${ }^{53}$ Similar voices were raised by the people and the press in Paris, where the criticisms were specifically directed at the Minister of Interior, Albert Sarraut. ${ }^{54}$ The politician resigned on 14 October 1934. On the same day, the Minister of Justice, Henry Cheron, was dismissed, under strong pressure exerted by the Minister of War, Marshal Philippe Pétain. ${ }^{55}$

According to press reports, the effects of the attack in Marseilles had a disastrous influence of the health of former President of France, Raymond Poincaré, who passed away on 15 October 1934, at the age of 74. His death was attributed directly to the murder of the Yugoslav monarch. Ilustrowana Republika quoted a statement by some unknown person from the former president's closest entourage: "The events in Marseilles, and the tragic deaths of King Alexander and Minister Barthou in particular, deeply affected Raymond Poincaré. His health, which had not been raising any concerns until recently, suddenly deteriorated [...]" ${ }^{56}$ Dziennik Poznański, in turn, would abstain from associating the politician's death with the assassination in Marseilles at first, ${ }^{57}$ but soon, this newspaper too published an article asserting that the former president of France was

${ }^{50}$ In English: “Marseilles has been dishonoured!”. Meysztowicz, Czas przeszły dokonany, p. 79.

51 "Demonstracje przeciw policji francuskiej”, Ilustrowana Republika, 280 (11 October 1934), p. 2.

52 “Wyrok śmierci na króla Aleksandra”, Ilustrowana Republika, 281 (12 October 1934), p. 2.

53 The statue was erected in Paris in 1936. It depicts King Alexander I on horseback, as well as Marshal Louis Franchet d'Esperey standing on his right side and King Peter I on the left. Behind both the marshal and the king stand two more unidentified characters. The men around Alexander I's horse seem to be paying homage to the king. The monument was designed by Maxime Real del Sarte.

${ }^{54}$ Demonstracje przeciw policji francuskiej, p. 2.

55 During the meeting of the Council of Ministers, Pétain scorned Chéron in his presence, in the following words: "We all feel that burden it is high time we got rid of", "Dramatyczna dymisja ministra Cherona", Ilustrowana Republika, 284 (15 October 1934), p. 2.

56 "Śmierć b. prezydenta Francji, R. Poincarego", Ilustrowana Republika, 285 (16 October 1934), p. 1 .

57 “Rajmund Poincaré nie żyje”, Dziennik Poznański, 237 (16 October 1934), p. 3. 
truly ravaged by the circumstances. ${ }^{58}$ All these events soon led to the resignation of the Doumergue's cabinet; his position was assumed on 8 November 1934 by Pierre-Étienne Flandin..$^{59}$

The transformations in the French government at the turn of October and November 1934 were the least severe punishment that Gaston Doumergue's personnel could have envisioned. As a matter of fact, the above-cited Meysztowicz pointed out, that the Yugoslav embassy in Paris had informed the French national and local authorities some time earlier about the risk of an assassination attempt, but these warnings have been disregarded. ${ }^{60}$ Such rumours circulated even among the officers of the guard of honour that hosted the monarch in Marseilles. Indeed, one of the officers obtained the following warning from his colleague, a member of the Croatian emigrant circles: "An attempt to assassinate King Alexander is to take place in Paris, with the use of a manual machine-gun. There will be many dead. I urge you to avoid being near the king". ${ }^{61}$ It should be stressed, however, that these reports about the possibility of an attempt on the Yugoslav monarch's life were merely speculations that would be hard to prove or verify today.

Shortly before the events in Marseilles, Queen Maria urged her husband not to go to France. The conversation of the royal couple was overheard by one of the King's servants, who referred it in the following terms: "Queen Maria [...] had a bad feeling, she begged and pleaded her husband, imploring him to forgo his voyage to Paris. Her efforts amounted, however, to nothing [...] as the king replied firmly: I cannot abandon this plan, as it is crucial to peace in the Balkans". ${ }^{62}$ The President of the Yugoslav Parliament, former mayor of Belgrade and Yugoslav minister, Kosta Kumanudi, also attempted to prevent the monarch from going to France, having interrupted his own journey to Istanbul for this purpose. Kumanudi's behaviour was odd. In his conversation with the king, he referred to a disturbing premonition regarding the monarch's trip to France. The king ignored the warning, and the subject of "Kumanudi's premonitions" was no longer pursued by the Yugoslav press. ${ }^{63}$ It is nonetheless possible that, during his journey, Kumanudi had encountered rumours about the possibility of an attack that were spread by Croatian émigrés.

It is worth noting that part of the blame for the success of the attack lies with the police and other services that were supposed to provide safety during the royal visit. According to Głos Poranny, in addition to the above-mentioned issues,

58 “Dramat marsylski przyspieszył śmierć Poincaré'go", Dziennik Poznański, 238 (17 October 1934), p. 3.

59 "Le cabinet Doumergue se retire", Le Figaro, 313 (9 November 1934), p. 1.

${ }^{60}$ Meysztowicz, Czas przeszły dokonany, p. 79.

61 "Wyrok śmierci na króla Aleksandra”, Ilustrowana Republika, 281 (12 October 1934), p. 2.

62 "Królowa Marja błagała króla Aleksandra, aby nie wyjeżdżał do Francji”, Ilustrowany Kuryer Codzienny, 286 (15 October 1934), p. 5.

${ }^{63}$ Ibid. 


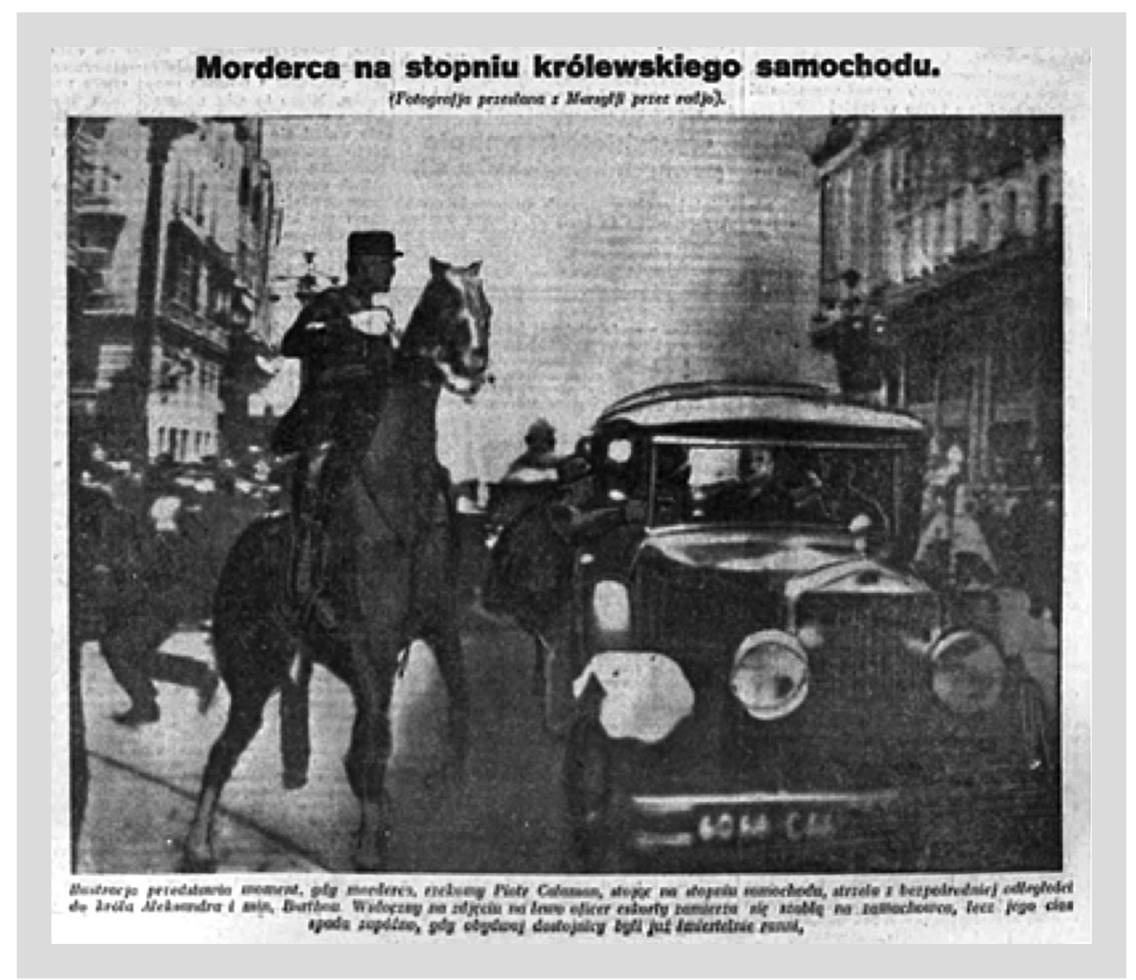

3. Photo of the moment of the attack in Marseilles; after: "Tajemnica spisku na króla Aleksandra i min. Barthou”, Ilustrowany Kuryer Codzienny, 283 (12 October 1934), p. 1.

such as the ill-advised placement of the officers along the king's route and the disregard for the rumours about a possible attempt at his life, it was also revealed that no police patrol had been grouped on the square near the stock exchange, right next to the spot where the assassination took place. ${ }^{64}$ Aware of their incompetence, the local police force proceeded with confiscating and censoring the film that clearly proved their shortcomings in securing the visit of the Yugoslav monarch. ${ }^{65}$ Another questionable circumstance was the mysterious death of the author of the film, Georges Mejat, which occurred six days after the assassination. ${ }^{66}$ It is possible that Mejat had been protesting against the confiscation and censorship of the film, to which the police responded by commissioning his murder; this issue, however, remains exclusively in the realm of speculation, given that an official medical certificate was issued, stating that Mejat had passed of natural causes. ${ }^{67}$

\footnotetext{
64 "Film stwierdza winę policji", Głos Poranny. Dziennik Polityczny, Społeczny i Literacki, 282 (12 October 1934), p. 3.

65 Ibid.

66 “Tajemniczy zgon kinooperatora”, Gazeta Lwowska, 245 (16 October 1934), p. 3.

67 Ibid.
} 
The Marseilles Police Department attempted to diminish their responsibility in the eyes of the public by assuring that they had only fired in the direction of the perpetrators, and that the accidental victims of the shooting were casualties of the assassin's accomplices, with whom he had surrounded himself during the attack. ${ }^{68}$ This explanation was, however, refuted by a forensic examination of the bullets found at the scene that fit either the murderer's weapon, or those belonging to the discredited police officers. ${ }^{69}$ Ilustrowany Kuryer Codzienny tried to defend the police force by stating: "Every crowd is a jungle that cannot be penetrated by even the sharpest officer's eye"; ${ }^{70}$ such attempts were nonetheless rare.

The French press even experienced a wave of criticism denouncing their police forces as infested with troublemakers, gangsters and bribe-takers. They were also chastised for their glaring negligence during King Alexander I's visit to Marseilles. The rhetorical question of why the Yugoslav monarch had not been accompanied by a squadron of cavalry, as is usual with this type of occasions, was posed. ${ }^{71} \mathrm{In}$ these circumstances, one could not really expect Gaston Domergue's cabinet to remain in power.

\section{Black birds over King Alexander's coffin}

The monarch's corpse was placed on board of the Dubrovnik the next day following the attack. The farewell to Alexander I was marked by a gloomy atmosphere. General Souchez ${ }^{72}$ paid his last respects in the company of seven officers at the police station where the king's corpse had been laid. Then, on the afternoon of 10 November 1934, the funeral procession walked down Canebière street, headed by French President Albert Lebrun, Queen Maria ${ }^{73}$ and other members of the Karađorđević family, as well as French ministers and representatives of the French army. ${ }^{74}$ The procession was accompanied by the sounds of the anthems of France and Yugoslavia. ${ }^{75}$

68 "Mordercę zastrzelili koledzy", Głos Poranny. Dziennik Polityczny, Społeczny i Literacki, 283 (13 October 1934), p. 1.

69 Марсељска трагедија, p. 6.

70 "Znaczenie i skutki zamachu", Ilustrowany Kuryer Codzienny, 283 (12 October 1934), p. 2.

71 "Gwałtowne ataki na policję francuską", Dziennik Poznański, 234 (12 October 1934), pp. 2-3.

72 First name unknown.

73 The queen fainted on hearing of the king's death. She then headed to Marseilles from Dijon, where they were supposed to reunite according to the original plan. Some newspapers reported that Queen Maria was pregnant at the time and lost her child as a consequence of her despair, but this information has not been confirmed elsewhere; "Powiadomienie królowej wdowy", Dziennik Poznański 233 (11 October 1934), p. 2; "Komplikacje polityczne na Bałkanach", Ilustrowana Republika, 280 (11 October 1934), p. 2.

74 “Ostatnia podróż króla Aleksandra do ojczyzny”, Ilustrowana Republika, 280 (11 October 1934), p. 1.

75 “Po zamachu w Marsylji”, Gazeta Lwowska, 242 (12 October 1934), p. 1. 
Meysztowicz described the grieving population of Marseilles, which flocked to pay their respects, in the following words:

[...] when the coffin draped in the Yugoslav flag touched the deck of the Dubrovnik, the noise of a huge eight-ton bell, traditionally heard only in exceptional circumstances, resonated from the peak of the Notre-Dame de la Garde cathedral erected on a hill overlooking the city from the eastern side of the Old Port, and thousands of heads turned to the almost 10-metre-tall gilded statue of the Madonna gleaming in the sun at the top of the tower, as if in silent reproach for not having protected Marseilles from this ignominious responsibility for the murder of King Alexander, even though its sons weren't culpable themselves. ${ }^{76}$

The destroyer carrying the monarch's body left the port of Marseilles around $4.25 \mathrm{pm}$. The vessel was escorted by two French destroyers and a division of their Yugoslav counterparts. When the Dubrovnik made it to the Adriatic Sea, a halt occurred as the British Mediterranean fleet wished to pay tribute to the monarch. The ship's commander consented. Eventually, the Dubrovnik arrived in Split in the early morning of 14 October 1934 between 5 and 6 am. ${ }^{77}$ Alexander's corpse was met by a memorial delegation headed by the monarch's uncle, Prince Arsen, as well as members of the government and representatives of the army. According to the estimates of Ilustrowany Kuryer Codzienny, a crowd of approximately one hundred thousand people gathered in Split to mourn the king. ${ }^{78}$

After the identification of the corpse by Prince Arsen and Yugoslav generals, a tribute was paid to the monarch. The coffin carrying his body was placed on the waterfront, and then, following the playing Yugoslav anthem and a memorial prayer, the procession marched towards the Split railway station. ${ }^{79}$ From there, the coffin was transported by train; first to Zagreb, where the monarch was bid farewell by approximately two hundred thousand Croats, and then, on 15 October 1934 , to Belgrade.$^{80}$ On that day, the coffin with the body of the monarch was put on public display at the reception hall of the royal palace. The people would pray and express their condolences from 6 am to $10 \mathrm{pm}$ for three consecutive days. ${ }^{81}$ Many Yugoslav citizens would fulfil this symbolic duty; countless memorial pilgrimages from all over the country were coming to Belgrade. ${ }^{82}$

\footnotetext{
76 Meysztowicz, Czas przeszly dokonany, p. 81.

77 “Разарач 'Дубровник' ноћи и отаџбину мртво тељо Краља Александра”, Политика, 9483 (11 October 1934), p. 1.

78 “Żałobny powrót króla-zjednoczyciela Jugosławji do Ojczyzny", Ilustrowany Kuryer Codzienny, 287 (16 October 1934), p. 2.

79 “Zwłoki króla Aleksandra przybyły do Jugosławji”, Gazeta Lwowska, 245 (16 October 1934), p. 1 .

80 “Непрекидан ланац ожалошћеног народа дуж пруге од Сплита до Београда дочекивао је воз с ковчегом Краља Ујединитеља", Политика, 9488 (16 October 1934), p. 1.

81 "Przysięga na wierność nowemu królowi”, Gazeta Lwowska, 243 (13 October 1934), p. 1.

82 "Pielgrzymi z całej Jugosławji do trumny", Ilustrowana Republika, 286 (17 October 1934), p. 4.
} 
The despair over the loss of the country's ruler was particularly evident among the Serbs. Demonstrations in honour of the monarch, where the participants would manifest their despair and curse the assassins aloud, were a common sight in the streets of the capital. ${ }^{83}$ Apart from Belgrade, numerous similar events took place in Ljubljana, Sarajevo, Skopje and Zagreb, where a variety of insults was thrown at Italy and Hungary. Many riots occurred, leading to several international incidents, such as the Italian consul getting roughed up in Ljubljana, or the attack on the Czechoslovak consulate in Zagreb; several Italians living permanently in Croatia and Slovenia were severely beaten. ${ }^{84}$ Jewish shops were also targeted in all these cities (and Osijek as well); the Jewish minority had no apparent role in the context of the assassination, nor in the Yugoslav political disputes in general, but with the anti-Semitic propaganda being common everywhere in Europe at the time, the Jews had become a convenient opportunity to vent any negative emotions. ${ }^{85}$ Besides, a somewhat absurd situation occurred in Ljubljana and Sarajevo, where the protesters were loudly cursing the Croats, several of whom have even been assaulted, while at the same time in Zagreb, the Croats too were calling for the murderers of King Alexander to be found and tried. ${ }^{86}$

The funeral of the monarch took place on 18 October 1934 in Belgrade and Topola. The official ceremony started at 8 am in the capital of Yugoslavia, with a memorial service celebrated by the Patriarch of the Serbian Orthodox Church, Varnava I. Memorial services also began simultaneously in all other cities of the Kingdom of Yugoslavia, usually lasting until the end of the main ceremonies in Belgrade and Topola. Around $9 \mathrm{am}$, the funeral procession set out from the cathedral in Belgrade bound for the railway station, from where the coffin would be transported to Topola. ${ }^{87}$

A large cross was carried at the head of the funeral procession, followed by a cavalry unit and flags of all Yugoslav regiments. Behind those walked troops of the Yugoslav and foreign armies, followed by the master of ceremonies Varnava

83 "Нема речи којима би це могао описати бол народа", Политика, 9487 (15 October 1934), p. 8.

84 As a result, the Italian consul in Ljubljana left the country. "Burzliwe manifestacje w Jugosławji", Ilustrowana Republika, 281 (12 October 1934), p. 4; "Demonstracje w Jugosławji”, Ilustrowana Republika, 282 (13 October 1934), p. 1; “Antywłoskie demonstracje w Jugosławji”, Gazeta Lwowska, 244 (14 October 1934), p. 1.

${ }^{85}$ Following the capture and death of Chernozemski, it was revealed that he had actually been circumcised because of his condition called phimosis. The dissemination of this information could be attributed to the increasing hostility towards Jews in Yugoslavia; "Pawelicz i Kwaternik aresztowani”, Głos Poranny. Dziennik Polityczny, Społeczny i Literacki, 289 (19 October 1934), p. 5.

86 "Burzliwe manifestacje w Jugosławji", Ilustrowana Republika, 281 (12 October 1934), p. 4; "Demonstracje w Jugosławji”, Ilustrowana Republika, 282 (13 October 1934), p. 1; “Antywłoskie demonstracje w Jugosławji”, Gazeta Lwowska, 244 (14 October 1934), p. 1.

87 "Wśród łkań i szlochu tysięcznych tłumów", Dziennik Poznański, 241 (20 October 1934), p. 3; “Zwłoki króla Aleksandra spoczęły w mauzoleum”, Gazeta Lwowska, 249 (20 October 1934), p. 1. 


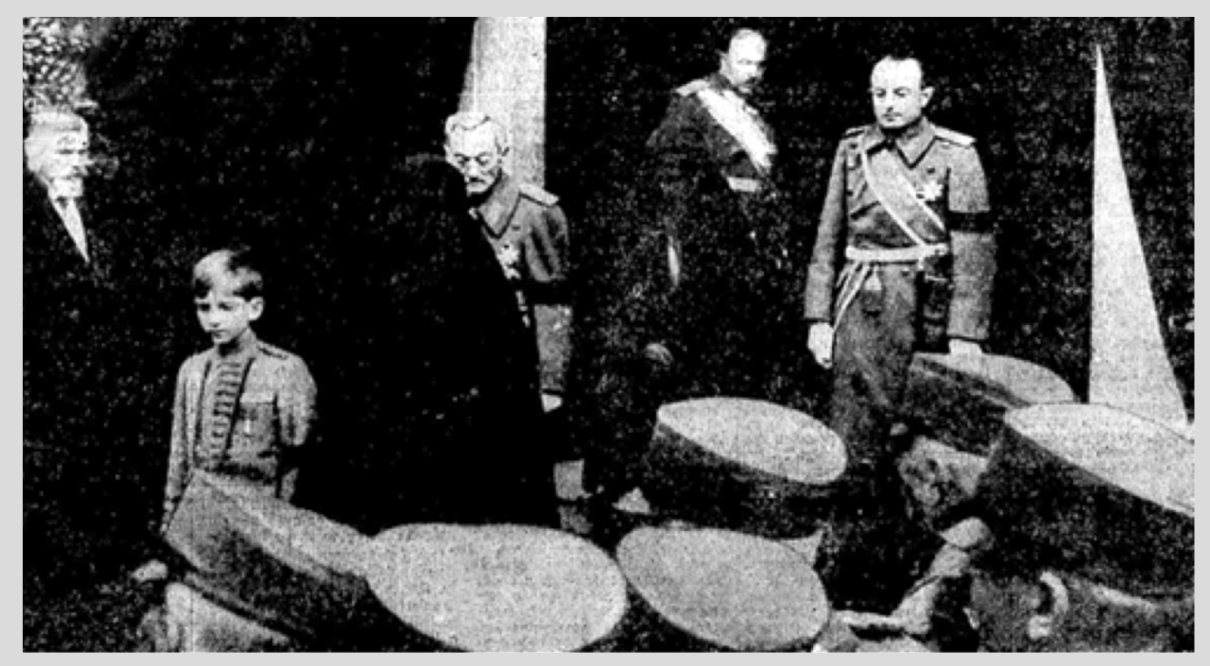

4. Meaningful photo taken at King Alexander's funeral; left to right: Peter II, heir to the throne, with his mother dressed in black, Prince Arsen, paternal uncle of the murdered monarch, and Arsen' son, Regent-Prince Paul, cousin of King Alexander I and de facto leader of the Kingdom of Yugoslavia after the latter's death; after: “Престоница и душа Југославије, Београд, велики у своме болу, опростио це јуче са својим витешким краљем ујединиетељем”, Политика, 9491 (19 October 1934), p. 1.

surrounded by chevaliers of the Order of Karađorđe's Star and clergymen, patriarchs and bishops of other denominations. The presence of one more participant was particularly moving: the monarch's favourite horse led by two royal guards. Behind the stallion, the supreme commanders of the Yugoslav Army were carrying the royal insignia. Next were about thirty slowly rolling cars carrying wreaths from the people and officials, finally followed by the modest coffin with the remains of the king, drawn by a team of four horses. Behind the coffin walked the monarch's son, Peter, wearing a Yugoslav Falcon outfit, his mother, Queen Maria, and all members of the Karađorđević family, followed by delegates of foreign states, and then - masses of Yugoslav citizens. ${ }^{88}$

The subsequent part of the funeral ceremony began at $1 \mathrm{pm}$ in Topola. As the funeral procession was moving by train towards the king's beloved town, dramatic scenes were playing along the route. The people that had gathered there fell to their knees as the convoy was passing, holding lighted candles and lamenting. The provincial town of Topola was so crowded, that the number of spectators was several times higher than the local population. The funeral ended at $1.45 \mathrm{pm}$, when the coffin with the body of the monarch was laid in the St. George mausoleum atop the Oplenac mountain. ${ }^{89}$

88 Ibid.

${ }^{89}$ Ibid. 
King Alexander I was therefore entombed in the same place as his father, grandfather, great-grandfather and many other ancestors. His coffin has been placed between the coffins of King Peter I and Prince Alexander. The monarch was buried in the mausoleum as the Knight-King Alexander I the Unifier. This honour was conferred to him posthumously on 11 October 1934 by act of the parliament. ${ }^{90}$ A yearlong period of national mourning in the Kingdom of Yugoslavia was announced, which was to end on 9 October $1935 .{ }^{11}$ One subject, however, was long kept secret from the Yugoslav public, namely the king's tattoo: a large, single-headed eagle with outstretched wings, whose head was adorned with a crown. The tattoo occupied a large part of Alexader's chest. Its meaning stemmed from Prussian heraldry. ${ }^{92}$

All the stages of the main funeral ceremony were attended by approximately half a million people, among whom were leaders of the Yugoslav opposition. ${ }^{93}$ Shortly after the attack in Marseilles, the leader of the Slovenian opposition, Anton Korošec, stated: "At a time when the entire Yugoslav nation mourns the death of its great king, everything should be forgotten. We have to live and work for Yugoslavia". ${ }^{94}$

His words were a reference to his internment in May 1932, a decision which Korošec considered a direct initiative of King Alexander I. However, in the face of the latter's death, all conflicts have been forgotten. An imminent amnesty for other opposition politicians was also expected. It is also worth noting that the domestic opposition circles had distanced themselves from the activities of Yugoslav émigrés.

The king's funeral was also attended by many leading political figures. ${ }^{95}$ Poland was represented by the commander of the $2^{\text {nd }}$ Cavalry Division in Warsaw, General Bolesław Wieniawa-Długoszowski, accompanied by other high-rank officers and

90 "Намесници краљевске власти положили су пред народним представнистшом заклетву на верност Краљу Петру II”, Политика, 9484 (12 October 1934), p. 1.

91 “Żałoba w Belgradzie”, Ilustrowany Kuryer Codzienny 293 (24 October 1934), p. 15.

92 Blic (newspaper), http://www.blic.rs: V. MT., "Kralj Aleksandar imao tetovažu velikog orla" (access: 7 March 2014).

93 The funeral ceremony was attended, i.a., by Anton Korošec and Ljubomir Davidović. Maček was absent due to his incarceration.

94 "Wszystko powinno być zapominane, gdy Jugosławja płacze", Ilustrowany Kuryer Codzienny, 287 (16 October 1934), p. 2.

95 In the photos published in Politika, one can almost immediately notice Hermann Göring President of the Reichstag, founder of the Gestapo, Prime Minister of Prussia and multiple-time Minister of the Third Reich - most often seen in the company of the French Marshal Philippe Pétain. It was Göring who, with the megalomania typical of him, authored the inscription on the German wreath laid before the king's coffin: "To their former heroic opponent with deepest feeling - the German Army". Otherwise, the photos also depict such politicians and military figures as: French President Albert Lebrun, German General Johannes Blaskowitz, King Carol II of Romania, Prince George, Duke of Kent, British Admiral William Wordsworth Fisher, Czechoslovakian Foreign Minister Edvard Beneš, Czechoslovakian Prime Minister Jan Malypetr, Turkish Foreign Minister Tevfik Rüştü Aras, and Prince Kiril of Bulgaria; among them also many high-rank officers from the English, Bulgarian, Czechoslovakian, Greek, French, German, Turkish, and other armies. 
Polish envoy in Belgrade, Władysław Günther-Schwarzburg. ${ }^{96}$ It should be mentioned that the Polish civil and military authorities expressed great concern regarding the incident in Marseilles. The Polish foreign minister Józef Beck, who, on the day of the attack, was partaking in a hunt at Chodzież as guest of President Mościcki, has returned to Warsaw by plane immediately upon hearing the news of the assassination, in order to transmit condolences to the Yugoslav envoy Branko Lazarević. The very next day, the head of Polish diplomacy also expressed his sympathy at the French Embassy at the hands of the Ambassador Jules Laroche. The same symbolic gesture was performed by the head of cabinet at the Ministry of War, Lieutenant Colonel Adam Korwin-Sokołowski on behalf of Marshal Józef Piłsudski, and by Prime Minister Leon Kozłowski on behalf of the Polish Government. Both the Yugoslav mission and the French Embassy issued books of condolences, where members of the government, high-rank officers, senators, deputies and representatives of local authorities could pay their respects. ${ }^{97}$ An official letter of condolences was also sent to Belgrade by the Archbishop of Warsaw and Metropolitan of All Poland of the Polish Orthodox Church, Dionizy. ${ }^{98}$

Shortly after the funeral, in an interview for the Italian newspaper La Stampa, General Bolesław Wieniawa-Długoszowski stated as follows: "The terrible news of the death of the king evoked an indescribable feeling throughout the country, especially among the military; it felt like a thunderbolt. I am telling you this as if you were not a journalist, but one my fellow officers. The great regard that we had for King Alexander, as a living symbol of heroism, will remain deeply engraved in our hearts. We, Poles, understand like few others how great of a loss this is for Yugoslavia, as we understand how crucial for a nation is its leader". ${ }^{99}$ Numerous public ceremonies were also held throughout Poland to commemorate King Alexander I as a war hero and champion of international peace. ${ }^{100}$

\section{Who ruled Yugoslavia after the death of King Alexander I?}

Following the king's demise, his eldest son, 11-year-old Peter, formally assumed power. This was confirmed by a proclamation of the government of Prime Minister Nikola Uzunović, issued on 10 October 1934, which stated as follows: "On the 9th day of October, at $4 \mathrm{pm}$, our great king Alexander the First fell victim to

96 "Cała Europa składa hołd bohaterskiemu królowi”, Gazeta Lwowska, 247 (18 October 1934), p. 1.

97 "W Warszawie", Gazeta Lwowska, 242 (12 October 1934), p. 1.

98 "Żałoba w Polsce", Dziennik Poznański, 234 (12 October 1934), p. 3.

99 "Deklaracja gen. Długoszowskiego", Dziennik Poznański, 242 (21 October 1934), p. 3.

100 "Żałobna akademja ku czci Króla-Bohatera”, Dziennik Poznański, 240 (19 October 1934), p. 4; "Akademja żałobna ku czci Aleksandra I", Ilustrowany Kuryer Codzienny, 287 (16 October 1934), p. 4. 
a heinous attack in Marseilles. The martyr-king's own blood sealed the great work of peace, for which he had undertaken his journey to allied France. According to the art. 36 of our Constitution, the eldest son of the king, His Majesty Peter the Second, now sits on the throne of the Kingdom of Yugoslavia. The government, the royal army and the navy have all sworn their allegiance to His Majesty Peter the Second [...]". ${ }^{101}$ Then, on 11 October 1934, on the basis of an act adopted during an extraordinary session of parliament, Peter Karađorđević was officially and legally proclaimed King of Yugoslavia. ${ }^{102}$

On the day of the assassination, Prince Peter was in Wiltshire, about $130 \mathrm{~km}$ from London. The boy had just begun his education at the Sandroyd Preparatory School one month earlier, with a view to ascend one day the Yugoslav throne. ${ }^{103}$ However, he was granted this honour much earlier than he could have anticipated. On that fateful day, Prince Peter was cheerful and took active part in a school football game. ${ }^{104} \mathrm{He}$ learned of his father's death the following morning. The unpleasant duty of informing the young prince about the tragedy was carried out by the Yugoslav envoy in London named Đurić, ${ }^{105}$ who also immediately announced that Peter would be taking over the Yugoslavian throne. ${ }^{106}$ The reaction of the prince has been described in Dziennik Poznański as follows:

"The young monarch showed exceptional composure; quietly sobbing, pale, he left accompanied by the Yugoslav deputy [...] to the car, where an inspector of the Scotland Yard was already seated next to the chauffeur". ${ }^{107}$ Peter's grandmother, Queen Marie of Yugoslavia, who was staying in London at the time, left England with him by train bound for France. Besides the Scotland Yard, they were also accompanied by French police officers. ${ }^{108}$

The mayor of Belgrade, Milutin Petrović, made a special appeal to his citizens, urging them to forget about the death of King Alexander I for a brief moment, so that his successor could be welcomed with dignity; and, as a matter of fact, the prince was greeted passionately by the residents of the capital as soon as he set foot in Yugoslavia. ${ }^{109}$ Peter II then received an oath of allegiance from Alexander I's cousin, Prince-Regent Paul, senator and Minister of Education Radenko Stanković, and the head of the Sava banovina, Ivo Perović. ${ }^{110}$

\footnotetext{
101 "Intronizacja 11-letniego króla Jugosławji”, Ilustrowana Republika, 280 (11 October 1934), p. 1.

102 Намесници краљевске власти, p. 1.

103 “Król umarł, niech żyje król!”, Dziennik Poznański, 233 (11 October 1934), p. 2.

104 Ibid.

105 First name unknown.

106 Intronizacja 11-letniego króla Jugosławji, p. 1.

107 "Król Piotr II przybył do Paryża strzeżony bacznie przez policję", Dziennik Poznański, 234 (12 October 1934), p. 2.

108 Ibid.

109 "Radosne powitanie", Głos Poranny. Dziennik Polityczny, Społeczny i Literacki, 283 (13 October 1934), p. 4.

110 Ibid.
} 


\section{Dziecko na tronie}

Na urodziny ojca, króla Aleksandra, mały Piotruś zainstalował własnoręcznie dzwonek elektryczny

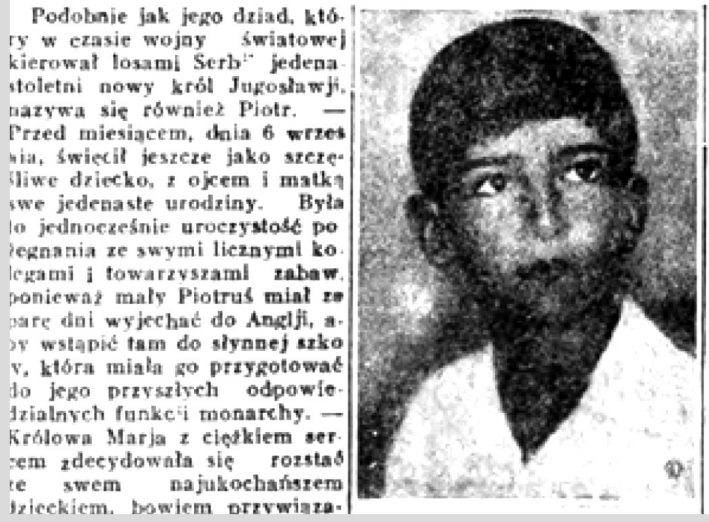

bracl Tomislawa i Andrzeja. Ze srezegolna pilnoscia studjo. wal geografie i jut jako 9-jeln! chlopezyk naszkicowat sam mape Bledu i pieknego jexiora, na kiórej prawie wsystkic wezepoly byly seisle. Podeza. swych exestych preejaidiek bodriq po jeriorze Bled, widzialo sie mfodero ksi vila $z$ iego wiel. ka mapa. nadi jacego I powaga k terunek wedle tej wlasnorcez. nie skonstruowanej karty. Od dwuch lat wainteresowa bie ksiecla szezegolnle intersym nie skierowato się w kierunk masryn. Najmilszemi jęo ra. bawknmi staly sie druty, cewki I lampy tadjowe. Doskonaly $e$. gramin swej zreernobel zdal podezas ostatnich urodzin króla Aleksandra. Wóweras kslate

5. Fragment of an article on the then 11-year-old King Peter II; after: "Dziecko na tronie”, Głos Poranny. Dziennik Polityczny, Społeczny i Literacki, 282 (12 October 1934), p. 2.

Prince-Regent Paul assumed de facto authority in the country in order to govern until King Peter II came of age. Głos Poranny defined Paul Karađorđević as a seasoned diplomat and polyglot, akin to hunting, golf, aviation and cars, as well as a person hitherto uninvolved in politics. As he came to power, it was commonly believed that he would grant amnesty to opposition politicians and exclude military officers from key government posts, given the Prince-Regent's conviction that the military should not interfere in politics. ${ }^{11}$ Stanković and Petrović for their part would take care of the deceased monarch' estate, as well as his family's current affairs, with special emphasis on the education of his sons. King Alexander's will, which he had drawn up ten months before his murder, i.e. on 5 January 1934, has therefore been fulfilled. ${ }^{112}$

Głos Poranny pointed out that merely one month before the assassination, on 6 September 1934, the eldest son of King Alexander I had been celebrating his eleventh birthday. The young prince has always been a resolute child, fascinated by geography and engineering. For King Alexander I's $45^{\text {th }}$ birthday, he actually built an electric bell by himself as a gift. Głos Poranny also stressed Queen Maria's strong connection with her three sons, for whom she cared - to quote the article

111 "Monarcha i prawdziwy władca", Głos Poranny. Dziennik Polityczny, Społeczny i Literacki, 289 (19 October 1934), p. 2.

112 АЈ, Двор Краљевине Југославије, ref. 74-23-40, Тестамент краль Александра I Карађорђевића о одређивағу старатеља юеговој малолетној деци, 5 January 1934. 
- "[...] as an ordinary mortal would". ${ }^{113}$ The queen paid great attention to the upbringing and education of her children. The same newspaper quoted the words that she spoke to Peter during one of his lessons: "Serious tasks await you in life, and if you do not understand something by yourself, you will lack the power to impose them to others". ${ }^{114}$ After the attack in Marseilles, these words suddenly gained a real, yet unexpected dimension.

\section{Search for the instigators}

Even before the king's body was brought to Belgrade, the Yugoslav authorities had launched an investigation in order to identify Chernozemski's accomplices. It soon became apparent that the direct organisers of the attack were the Ustaše Ante Pavelić and Eugen Dido Kvaternik. The attack was carried out in consultation with the leader of the Macedonian revolutionaries, Ivan Mihailov. Near the end of August 1934, a meeting between Pavelić and Mihailov took place at the Hotel Continentale in Rome, during which various alternatives for the assassination of the monarch were discussed. Then, in September 1934, the two men met again in Munich, where they established their final plan in detail, including the decision regarding the transfer of a large sum of money to the perpetrators. ${ }^{115}$

In addition to Chernozemski, three more common criminals affiliated with the Croatian Ustaše were designated to carry out the assassination: Mijo Kralj, Ivan Rajić and Zvonimir Pospišil. The group obtained French passports from Hungarian intelligence services. At the beginning of October 1934, Kvaternik was included in the direct execution of the attack in Marseilles, providing the perpetrators with money, weapons and ammunition, and acquainting them with the planned route of the monarch. ${ }^{116}$ Kvaternik, who was using the false name Kramer, then told the assassins: "You know what you have to do. The king is coming to Marseilles today. Shoot him". ${ }^{117}$ Pospišil expressed some doubt about the organisation of the attack, for fear of injuring or killing innocent people by accident. Kvaternik reacted nervously to his remarks and excluded Pospišil from the plan. ${ }^{118}$

Most of the information about the organisation and the circumstances of the attack were obtained by the French intelligence services following a quick

\footnotetext{
113 “Dziecko na tronie”, Głos Poranny. Dziennik Polityczny, Społeczny i Literacki, 282 (12 October 1934), p. 2.

114 Ibid.

115 "Ухваћени су организатори марсељског атената емигранти Анте Павелић и Еуген Кватерник”, Политика, 9492 (20 October 1934), p. 3; “Алтернатор су посши са Јанка Пусте у Мађарској”, Политика, 9492 (20 October 1934), p. 5.

116 Ibid.

117 “Morderca króla był Macedończykiem”, Gazeta Lwowska, 247 (18 October 1934), p. 1.

118 Ibid.
} 
capture of Kralj, Rajić and Pospišil. ${ }^{119}$ The Ustaše used several false passports, ${ }^{120}$ but, after being subjected to brutal interrogation, the three men soon broke down and began to disclose important information and testify against the organisers of the assassination. ${ }^{121}$ The criminals admitted that, in the event of a failure in Marseilles, they were obliged to renew their attempts in other parts of France or in Switzerland, where, according to their knowledge, the monarch meant to go next. ${ }^{122}$ Had Chernozemski missed his chance in Marseilles, Kralj was supposed to fire more shots from the crowd. However, the man eventually panicked, choosing to leave the city in haste instead. ${ }^{123} \mathrm{~A}$ search of the rooms used by the assailants in different parts of France resulted in the finding of two bombs and three automatic pistols, as well as numerous Croatian separatist leaflets and literature. ${ }^{124}$

The testimony of Chernozemski's accomplices in France led to a broad wave of arrests among Balkan émigrés, including Svetozar Pribićević, ${ }^{125}$ a once prominent Yugoslav politician, who was incriminated by Kralj's testimony. On the day of the attack, Kralj had told the receptionist in Aix-en-Provence that he was going to meet with Pribićević. ${ }^{26}$ The house of the former Yugoslav minister of interior was found to contain a large amount of literature calling for the division of Yugoslavia. All individuals that Pribićević had made contact with were also interrogated. ${ }^{127}$ Numerous witnesses showed up at the police stations in Marseilles,

119 Kralj and Rajić reunited with Pospišil near the French border, in the town of Thonon-les-Bains, from where they attempted to escape into Switzerland. The broad investigation undertaken by the Marseilles and Paris police departments resulted in many arrests, often among innocent people, "Schwytanie na granicy" and "Rewizje i aresztowania", Głos Poranny. Dziennik Polityczny, Społeczny i Literacki, 282 (12 October 1934), p. 1.

120 Each of the criminals used two false passports. Kralj had documents issued in the names of Malny and Willinger, the two passports of Rajić bore the names Beneš and Sever, and Pospišil's-Novak and Ungar. The latter was sought by the Yugoslav police on a charge of murder, for which he has been sentenced to death. “Tajemnica zamachu wyjaśniona!", Głos Poranny. Dziennik Polityczny, Społeczny i Literacki, 283 (13 October 1934), p. 1.

121 Ухваћени су организатори, р. 3; Алтернатор су посши, p. 5.

122 "Emigranci chorwaccy - mordercami króla", Ilustrowana Republika, 282 (13 October 1934), p. 1; “Aresztowanie wspólnika Gergjewa”, Gazeta Lwowska, 246 (17 October 1934), p. 1.

123 “Malny miał strzelać z Kelemanem”, Ilustrowana Republika, 286 (17 October 1934), p. 3.

124 Ibid.

125 “Aresztowanie b. ministra Prybicewicza”, Gazeta Lwowska, 253 (25 October 1934), p. 1.

126 “Morderca miał wspólników”, Dziennik Poznański, 234 (12 October 1934), p. 1.

127 Pribićević was an easy target for accusations, as he had published one year earlier in Paris the anti-royalist book The dictatorship of King Alexander (La dictature du roi Alexandre), and maintained constant, well-documented contacts with Serbs and Croats living in Yugoslavia. Although he was a Knight of the Legion of Honour, the French police allegedly mistreated him during the interrogation. According to his memoirs edited in 1990 by Bogdan Krizman, Dražen Budiša and Božidar Petrač, he was held in solitary confinement. When no link was found between him and the assassins, he was released from detention, but was also immediately expelled from France, on the basis of "hard-to-prove" connections with the organisers of the assassination. Using this case as a precedent, the French authorities then proceeded with 
Paris and other French cities to report, with great zeal, any sightings of suspicious foreigners in their vicinity. ${ }^{128}$ An extensive search party by the French police led to the capture of indirect participants in the assassination of King Alexander I, such as Kvaternik's wife, Marija Vondrać ("Beautiful Marija"), as well as the fraudster Mio Bzik. Both performed organisational and intelligence duties in Marseilles. ${ }^{129}$

Ten days after the attack, i.e. on 19 October 1934, Pavelić and Kvaternik were arrested in Turin, where they were hiding. Both explicitly denied any involvement in the assassination. ${ }^{130}$ Pavelić maintained that he had never been to Marseilles, although the passport issued in Hungary that was found in his possessions indicated otherwise. ${ }^{131}$ Kvaternik too asserted that he disregarded all allegations, having spent the previous ten months in Berlin, and claimed that he could provide proof. ${ }^{132}$ The French authorities reacted in a manner most baffling, choosing not to submit a request for extradition to Mussolini. ${ }^{133}$ Such a request was filed, on the other hand, by Yugoslavia, but Il Duce refused to give out Pavelić and Kvaternik to the Yugoslav judiciary. ${ }^{134}$ The Italian dictator responded by stating that he had already displayed a maximum of loyalty to Yugoslavia by ordering his police to arrest Pavelić and Kvaternik in the first place, even though he could have confined himself to requesting their supervision. ${ }^{135}$

Uzunovićs government expressed their disappointment with the French authorities, as they had an opportunity to intercept the organisers of the attack from under Italian protection. From this moment, the relations between France and Yugoslavia began to deteriorate gradually. Gazeta Lwowska noted that by end October 1934, many Yugoslav members of the leading organisation for FrenchYugoslav friendship had resigned en masse, even leading to the closure of its branch in Skopje. ${ }^{136}$ In early November 1934, Božidar Maksimović, personally an advocate of friendship between Yugoslavia and France, had lost the position of Minister of Justice. ${ }^{137}$ Simultaneously, the relations between France and the Little Entente

throwing many other Yugoslav emigrants out of the country or rendering their stay tedious to point of inciting them to leave on their own. Pribićević died in Prague in 1936.

128 “Kelemen nie był Macedończykiem?”, Dziennik Poznański, 235 (13 October 1934), p. 2.

129 "Organizacja spisku”, Dziennik Poznański, 242 (21 October 1934), p. 3.

130 “Aresztowanie Pawelicza i Kwaternika we Włoszech", Gazeta Lwowska, 294 (10 October 1934), p. 3.

131 "Pertraktacje o wydanie Pavelicza i Kvaternika", Ilustrowany Kuryer Codzienny, 294 (23 October 1934), p. 3.

132 "Pawelicz i Kvaternik wypierają się winy", Gazeta Lwowska, 252 (24 October 1934), p. 3.

133 Ibid.

134 АЈ, Централни пресбиро Председниства Министарског савета КJ, ref. 38-103-240, Оптужницом против атенатори и оганизатора марсељског атената.

135 "Włochy wykazały maksimum lojalności", Ilustrowany Kuryer Codzienny, 293 (24 October 1934), p. 15.

136 "Zmiana nastrojów wobec Francji zaznacza się na terenie Jugosławji”, Gazeta Lwowska, 255 (27 October 1934), p. 1.

137 His position was assumed by Dragutin Којіс́, Устави и владе, р. 273. 
soured as well, a consequence correctly predicted by Ilustrowana Republika already on 11 October 1934. ${ }^{138}$ As for Pavelić and Kvaternik, they remained in Italy, where they would await their trial, set for 29 March 1936, in relatively comfortable conditions. In contrast, Kralj, Rajić and Pospišil were all held in remand and eventually sentenced to life imprisonment following a high-profile trial, which took place on 12 February 1936 in Aix-en-Provence, where the assassins had been hiding on the day before the assassination. The prosecution demanded the death penalty for the accomplices of the killer; such voices were also raised by the French and Yugoslav public opinion. The trial, however, raised a lot of controversy. In Yugoslavia, it was generally believed that Mussolini himself had taken the killer's accomplices under his protection, thus saving them from a death sentence. ${ }^{139}$ Pospišil eventually died in mysterious circumstances at the Caen prison in 1940; the same fate was met one year later by Kralj in Fontevraud. Only Rajić has been released from prison, on 12 December 1941, due to his deteriorating health. He then returned to Croatia, where he died in $1944 .{ }^{140}$

The role of Ivan Mihailov, on the other hand, became marginal over the course of the investigation. This was due to the decreasing importance of the Macedonian revolutionary organisation, giving way to that of the Ustaše. Mihailov's persona aroused, however, interest among the press. For instance, Ilustrowana Republika claimed, in an article from 11 October 1934, that King Alexander I may have been murdered out of vengeance by Macedonian revolutionaries. The Yugoslav monarch had indeed reached an agreement in May 1934 with Bulgarian Prime Minister, Kimon Georgiev, regarding the removal of IMRO cells from Bulgarian territory. ${ }^{141}$ Ilustrowana Republika also cited an interview with Mihailov, that had taken place in Istanbul some time before the attack in Marseilles. During the conversation, the IMRO leader called himself an idealist and a nationalist, whose only goal was the establishment of an independent Macedonia. A blunt remark by the Greek journalist prompted him to reply in all seriousness that the Macedonian revolutionaries belonged to their organisation for ideological motives and did not receive any money for their activities, nor did said activities entail killing people. ${ }^{142}$ Mihailov also asserted his disregard for the death sentence in absentia he received in Bulgaria, then added: "Why be afraid of death? I certainly am not! Besides,

138 "Komplikacje polityczne na Bałkanach", Ilustrowana Republika, 280 (11 October 1934), p. 2.

139 АЈ, Централни пресбиро Председниства Министарског савета КJ, ref. 38-104-241, Proces des assassins de S.M. Roi Alexandre Ier de Yougoslavie et de S.E.M. Louis Barthou ministre des affaires etrangères de la France, 5-12 February 1936.

140 АЈ, Централни пресбиро Председниства Министарског савета КJ, ref. 38-476-628; Извештај о пресуди убииама Краља Александра, 12 February 1936; AJ, ref. 74-1/619-658; Винаверов извештај о проиесу у екс ан провансу, 19 February 1936; E. Kvaternik, Sjećanja i zapažanja 1925-1945: Prilozi za hrvatsku povijest, Zagreb, 1995, pp. 278-279.

141 “Komplikacje polityczne na Bałkanach", Ilustrowana Republika, 280 (11 October 1934), p. 5.

142 “Wywiad z przywódcą W.M.R.O.”, Ilustrowana Republika, 290 (20 October 1934), p. 3. 
dying in a bed is demeaning". ${ }^{143}$ The leader of the Macedonian revolutionaries was seen at the turn of September and October 1934 in Switzerland, but his participation in the assassination of Alexander I was being taken into consideration only in Yugoslavia. ${ }^{144}$

It is difficult to determine the role played by representatives of other European countries in the murder of the Yugoslav king. The fact that the assassins were trained in a terrorist facility on Hungarian soil is beyond any discussion. The journalists from Politika also put forth the bold thesis that the perpetrators had obtained passports from the Hungarian intelligence with the consent of Miklós Horthy, Regent of the Kingdom of Hungary, and Hungarian Prime Minister Gyula Gömbös. However, there is little risk in assuming that Mussolini himself supported the idea of murdering the Yugoslav monarch, as evidenced by his protection of Pavelić and Kvaternik, as well as the pressure asserted by him during the trial in Aix-en-Provence.

In October 1934, a strong wave of accusations fell on the Hungarian authorities on the part of Yugoslavia, France and Czechoslovakia. Both the governments and the press of these countries expressed their contempt. They demanded an international investigation on Hungarian territory in order to establish any local ties with the organisers of the attack in Marseilles. In view of these allegations and demands, Gömbös' government reacted nervously, denouncing the accusations as an uncalled slandering campaign and France's attempt to distance itself from moral responsibility for the consequences of the attack, caused by the incompetence of Doumergue's cabinet. The Hungarian press pointed out that a much larger Yugoslav diaspora resided in France, and that no anti-Yugoslav activities had been witnessed in Hungary, contrarily to those of Pribićević for instance. ${ }^{145}$ Czechoslovakia was also criticised for being allegedly more interested in pursuing its anti-Hungarian policies than in explaining the circumstances of the murder of the king. ${ }^{146}$

The Hungarian line of defence was later altered when Gömbös' cabinet issued an official statement stating that that none of the detained assailants were Hungarian nationals, and that the area of the purported terrorist camp in Janka Puszta had been thoroughly searched and supervised, even though they had been claiming previously that only a regular farm was located there. According to the authorities in Budapest, the governments of Czechoslovakia and France had allegedly inspired a smear campaign, aimed at destabilising Hungary at the expense of a grieving Yugoslavia. ${ }^{147}$ The stance of Gömbös' cabinet later became somewhat easier to defend with the appearance, in the Czechoslovak press,

143 Ibid.

144 Ibid.

145 “Mała Ententa atakuje gwałtownie Węgry”, Dziennik Poznański, 237 (16 October 1934), p. 2.

146 "Węgry protestują przeciw oszczerczej akcji”, Gazeta Lwowska, 247 (18 October 1934), p. 3.

147 "Węgry protestują przeciw oszczerczej kampanji”, Gazeta Lwowska, 249 (20 October 1934), p. 1. 
of several articles that pictured King Alexander I in an unfavourable light, accusing him of dismantling the Yugoslav state and displaying gross incompetence in foreign politics. ${ }^{148}$

The conflict between Hungary and the Little Entente and France entered a new act with a declaration stating the need for the internationalisation of the investigation regarding the incident in Marseilles, issued on 20 October 1934 by the council of the Little Entente in consultation with the relevant members of the Balkan Entente. In practice, the document was a call for cooperation in order to identify all the organisers and perpetrators of the attack (including the governments that could have inspired it), so that such acts of terror would no longer occur in Europe. Full solidarity with Yugoslavia was also expressed. The declaration had undoubtedly an anti-Hungarian character; even though the document did not explicitly mention Hungary, it was easily understandable that this country was the document's true recipient. ${ }^{149}$

Meanwhile, Gömbös' government naively reported that it had launched its own investigation on Hungarian territory. The Hungarian Prime Minister also announced that he was leaving to pay a visit to the "allied Polish nation", ${ }^{150}$ in order to distance himself from the unjust smear campaign directed against his country. Moreover, Gömbös confirmed in full force: "neither the Hungarian government, nor any official body for that matter; not even one single Hungarian citizen was involved in this murder". ${ }^{151}$ The Little Entente and the Balkan Entente did not have the instruments nor the pressure force to impose the opening of an international investigation on Hungarian territory.

\section{Conclusion}

The true instigators of the assassination of King Alexander I were never identified, although evidence suggests that Benito Mussolini was the mastermind of this crime, effectively exploiting the hostility of Croatian and Macedonian terrorists against the Karađorđević monarchy. Several years after the death of the king, an unexpected warming of Italian-Yugoslav relations occurred along with a gradual increase in influence of fascism and Nazism in the Kingdom of Yugoslavia. Eventually, the tripartite agreements between Belgrade, Rome and Berlin concluded during World War II effectively compromised the political efforts of King Alexander I, and that of Karađorđevićs' Yugoslavia in general.

148 "Pogrzeb króla Aleksandra-Zjednoczyciela", Gazeta Lwowska, 248 (19 October 1934), p. 1.

149 “Deklaracja państw Małej Ententy i Ententy Bałkańskiej”, Gazeta Lwowska, 250 (12 October 1934), p. 1.

150 “Premier Goemboes odpiera oszczerczą kampanję skierowaną przeciw Węgrom”, Gazeta Lwowska, 250 (21 October 1934), p. 1.

151 Ibid. 
The evaluation of Alexander I should not be unambiguous. He did undeniably suspend democracy in the country and declare himself its only leader. However, his motives went considerably beyond the idealistic and uncritical idea of democracy. At the beginning of January 1929, he attempted to save the unified state from an actual threat of breaking apart due to strong separatist tendencies, occasionally resorting to terrorist methods. His actions were therefore not motivated by the desire to gain or maintain power, which he enjoyed anyway as head of state, but by the need for radical measure in order to save a failing country. Only a leader blessed with the qualities of an outstanding statesman could make the risky decision of suspending basic democratic institutions, while establishing at the same time a regime that could still be perceived as a transitional, remedial response to the crisis. However, the accomplishment of King Alexander I's further objectives was tragically cut short by his shameful assassination in 1934. After his death, the state that he had established with his father and a group of seasoned politicians, came to a crossroads between maintaining internal stability and reconfiguring its position in the international scene. I believe that the Yugoslavia envisioned by the Karađorđevićs never got over the death of its most important guardian, and both the circumstances and consequences of the assassination described in the present article clearly prove that the sole objective of the perpetrators and their instigators was the destruction of the basic institutions of this state.

\section{Abstract}

The article discusses the circumstances of the assassination of King Alexander I of Yugoslavia in October 1934 in Marseilles, France. The results of research served as a basis for the analysis of the course of events related to the assassination of King Alexander I, including the political context of the murder, its direct background and the earliest consequences for both Yugoslavia and the international scene.

Within the broad spectrum of research issues involved in the assassination, there are some worthy of special attention, such as the organisation of King Alexander I's visit to France, the characteristics of the assassin, the internal situation in Yugoslavia after the monarch's death, the reactions of other governments to the event, and the investigation launched into the attack, followed by the steps taken in order to internationalise it.

The basic research material for the analysis consisted of Serbian and Polish press articles from the interwar period, which constitute not just a reliable source, but often the only source available - yet a truly fascinating one. Moreover, the findings demonstrated in the present article have been verified in relation to the (often insufficient) Polish and international literature in this subject, as well as the archival materials available at the Yugoslavian Archives in Belgrade.

The variety of approaches applied made it possible to discuss the circumstances of King Alexander's assassination in great detail, otherwise unavailable in just one single publication. It also reveals the incompetence of the French police of that time and explains, at least in part, the background of the plot to kill the Yugoslav king. 


\section{Bibliography}

\section{Sources}

\subsection{Archival materials}

Архив Југославије у Београду

Централни пресбиро Председниства Министарског савета КЈ Служебне новине Краљевине Југославије

Збирка фотографија Двора Краљевине Југославије Збирка међународних уговора

\subsection{Press}

"Blic", http://www.blic.rs

Dziennik Poznański, 1934

Gazeta Lwowska, 1934

Głos Poranny. Dziennik Polityczny, Społeczny i Literacki, 1934

Ilustrowana Republika, 1934

Ilustrowany Kuryer Codzienny, 1934

Kurier Poznański, 1934

Le Figaro, 1934, http://www.lefigaro.fr

Le Petit Parisien, 1932, 1934

Nowiny Codzienne, 1934

Nowy Kurier, 1934

Политика, 1934

\section{Literature}

Batowski H., Między dwiema wojnami 1919-1939. Zarys historii dyplomatycznej, Kraków, 2001. Bennett Ch., Yugoslavia's Bloody Collapse: Causes, Course and Consequences, New York, 1995.

Benson L., Jugosławia. Historia w zarysie, Kraków, 2011.

Ćirković S., The Serbs, Wiley-Blackwell, 2004.

Cox J. K., The History of Serbia, Greenwood, 2002.

Djokić D., Elusive Compromise. A History of Interwar Yugoslavia, London, 2007.

Essen A., Polska a Mała Ententa 1920-1934, Warsaw-Kraków, 1992.

Felczak W., Wasilewski T., Historia Jugosławii, Wrocław, 1985.

Garlicka A., Polska-Jugosławia 1934-1939. Z dziejów stosunków politycznych, WrocławWarszawa-Kraków-Gdańsk, 1977.

Gašparič J., SLS pod Kraljevo Diktaturo: Diktatura kralja Aleksandra in politika Slovenske ljudske stranke v letih 1929-1935, Ljubljana, 2007.

Giza A., Idea jugoslawizmu w latach 1800-1918, Szczecin, 1992.

Giza A., Narodziny i rozpad Jugosławii, Szczecin, 1994.

Glenny M., The Balkans 1804-1999: Nationalism, War and the Great Powers, London, 1999.

Goebbels J., Dzienniki, vol. 1: 1923-1939, vol. 2: 1939-1943, E.C. Król (pref. and ed.), Warszawa, 2013.

Janjatović B., Politički teror u Hrvatskoj 1918-1935, Zagreb, 2002.

Judah T., The Serbs: History, Myth and the Destruction of Yugoslavia, New Haven, 2009.

Lampe J. R., Yugoslavia as History. Twice There was a Country, Cambridge, 2000.

Meier V., Yugoslavia: A History of Its Demise, London, 1999. 
Meysztowicz J., Czas przeszły dokonany. Wspomnienia ze stużby w Ministerstwie Spraw Zagranicznych w latach 1932-1939, H. Batowski (pref.), Kraków, 1984.

Pavličević D., Historia Chorwacji, Poznań, 2004.

Payne S. G., A History of Fascism 1914-1945, Wisconsin, 1996.

Perica V., Balkan Idols: Religion and Nationalism in Yugoslav States, Oxford, 2002.

Petranović B., Istorija Jugoslavije, vol. 1, Belgrade, 1988.

Podhorodecki L., Jugosławia. Dzieje narodów, państw i rozpad federacji, Warszawa, 2000.

Robertson R., Roudometof V., Nationalism, Globalization, and Orthodoxy: The Social Origins of Ethnic Conflict in the Balkans, Greenwood, 2001.

Singleton F., Twentieth-Century Yugoslavia, London, 1976.

Stawowy-Kawka I., Historia Macedonii, Wrocław, 2000.

The Royal Family of Serbia, www.royalfamily.org

University of Belgrade, http://www.bg.ac.rs

Waldenberg M., Kwestie narodowe w Europie Środkowo-Wschodniej, Warszawa, 1992.

Walkiewicz W., Jugosławia, Warszawa, 2009.

Внатрешна македонска револуционерна организација - Демократска партија за македонско национално единство, http://vmro-dpmne.org.mk.

Македонска нација, http://www.mn.mk.

Михайлов, И. Избрани произведения, ed. К. Андреев, Sofia, 1993.

Народно позориште у Београду, http://www.narodnopozoriste.rs.

Тюлеков Д., Обречено родолюбие. ВМРО в Пиринско 1919-1934, Blagoevgrad, 2001.

Konrad Sebastian Morawski, Ph.D., political scientist and historian, author of numerous scientific and popular science articles on the history of Yugoslavia, and co-author of a university textbook about the Balkans (konrad.morawski@wp.pl). 